\title{
Possible Mechanism of Phorbol Diester-induced Maturation of Human Promyelocytic Leukemia Cells
}

\author{
Activation of Protein Kinase C
}

G. R. Vandenbark, Linda J. Kuhn, and James E. Niedel Department of Medicine, Division of Hematology-Oncology, Duke University Medical Center, Durham, North Carolina 27710

A potent inducers of differentiation of the promyelocytic leukemia cell line, HL-60. Soluble phorbol diester receptors from HL-60 cells were obtained from the cytosolic fraction and from the particulate fraction by either divalent ion chelation or detergent extraction. The partially purified soluble phorbol diester receptors required exogenous $\mathrm{Ca}^{2+}$ and phospholipid for maximal binding and displayed a dissociation constant $\left(K_{\mathrm{D}}\right)$ of $8.1 \mathrm{nM}$ for $\left[{ }^{3} \mathrm{H}\right]$ phorbol 12,13-dibutyrate. Phorbol diester analogues inhibited $\left[{ }^{3} \mathrm{H}\right]$ phorbol 12,13 -dibutyrate binding in a stereospecific manner consistent with their biologic potency. The soluble phorbol diester receptors prepared by all three methods copurified in a constant ratio with the $\mathrm{Ca}^{2+}$ / phospholipid-dependent protein kinase $C$ through ammonium sulfate precipitation, DEAE ion exchange, and gel filtration chromatography. Partially purified protein kinase $\mathrm{C}$ was directly activated by the phorbol diesters even in the absence of exogenous $\mathrm{Ca}^{2+}$. The ability of a series of phorbol analogues to activate the kinase correlated with their known activity as inducers of cell differentiation. In addition, phorbol diester stimulation altered the phosphate acceptor substrate profile of protein kinase $C$, at least in part, by alteration of the Michaelis constant $\left(K_{\mathrm{m}}\right)$. These data suggest that protein kinase $\mathrm{C}$ is the phorbol diester receptor and that phorbol diesterinduced macrophage maturation of HL-60 cells may be mediated by activation of intracellular protein kinase $\mathrm{C}$.

Address all correspondence to Dr. G. R. Vandenbark, Duke University Medical Center, Durham, NC 27710.

Received for publication 24 May 1983 and in revised form 29 September 1983.

J. Clin. Invest.

(c) The American Society for Clinical Investigation, Inc. 0021-9738/84/02/0448/10 \$1.00

Volume 73, February 1984, 448-457

\section{Introduction}

The phorbol diesters are a group of agents capable of tumor promotion when administered topically following subthreshold doses of a carcinogen (1). In addition to tumor promotion, a wide range of functional and biochemical changes have been ascribed to the phorbol diesters in numerous experimental systems (2). Recently, the phorbol diesters have been shown to induce differentiation of HL-60 cells to macrophagelike cells (3-5). Phorbol 12-myristate 13-acetate (PMA)' treatment brought about rapid cessation of DNA synthesis and cell proliferation. The cells became adherent and phagocytic, lost azurophilic granules, demonstrated increased levels of nicotinamideadenine dinucleotidase, nonspecific esterase, and acid phosphatase, became cytocidal and cytostatic for tumor targets, and synthesized a surface antigen reactive with anti-monocyte serum (6-9). Other effects of PMA on HL-60 cells have included increased polyamine levels $(10,11)$, altered phosphatidylcholine and triglyceride metabolism $(12,13)$, decreased synthesis of high-molecular-weight glycopeptides (14) and generation of potent procoagulant activity (15). The phorbol diesters exert these effects via stereospecific receptors (16-18).

The nature of the phorbol diester receptor and the possible mechanism by which the effects of the phorbol diesters were transduced across membranes had remained unknown. However, recently Castagna et al. (19) have shown that PMA produced a direct activation of the $\mathrm{Ca}^{2+}$ and phospholipid-dependent protein kinase, termed protein kinase $\mathrm{C}$. This is a novel protein kinase, originally described in brain (20), and widely distributed in mammalian tissues $(21,22)$ including various types of human leukemic cells (23). It has been partially purified from platelets (24) and peripheral lymphocytes (25) as well as highly purified from bovine heart (26), rat brain (27), and pig spleen (28). The kinase is cyclic nucleotide and calmodulin insensitive but phos-

1. Abbreviations used in this paper: CHAPS, 3-[(3-cholamido-propyl)dimethylammonia]-1-propane sulfonate; PDBu, phorbol 12,13-dibutyrate; $4 \alpha \mathrm{PDD}, 4 \alpha$-phorbol 12,13-didecanoate; PDD, phorbol 12,13didecanoate; PMA, phorbol 12-myristate, 13-acetate; PMSF, phenylmethylsulfonyl fluoride. 
pholipid and $\mathrm{Ca}^{2+}$ dependent and further stimulated by diacylglycerol. It may undergo limited proteolysis by calcium-dependent neutral protease (29). Using chelator extracts of the particulate fraction of rat brain, we recently tested the hypothesis that protein kinase $\mathrm{C}$ may indeed be the phorbol diester receptor (30). We found that stereospecific, saturable phorbol diester receptors copurified with protein kinase $C$ activity through several steps. In addition, we confirmed the observation of PMA activation of protein kinase $C$. After initial submission of this paper, others have now demonstrated specific phorbol diester receptors in mouse brain cytosol that copurified with a $\mathrm{Ca}^{2+} /$ phospholipid-dependent kinase activity through gel filtration (31). Indeed, Ashendel et al. $(32,33)$, using detergent extracts of the particulate fraction of mouse brain, have shown copurification to apparent homogeneity of a specific phorbol diester receptor and $\mathrm{a} \mathrm{Ca}^{2+} /$ phospholipid-dependent protein kinase. Operationally, three pools of phorbol diester receptors have been identified; a cytosolic pool which remains soluble even in the presence of $\mathrm{Ca}^{2+}$, a cytosolic pool that binds to membranes in the presence of $\mathrm{Ca}^{2+}$ and can be solubilized by chelator extraction of the $\mathrm{Ca}^{2+}$ membranes, and a membrane pool that resists chelator extraction and requires detergent treatment for solubilization.

We have now extended these observations to the human leukemia cell line HL-60, in which the phorbol diesters exert well characterized biological effects. Utilizing all three of the aforementioned fractions, the cytosolic fraction, the chelator extract, and the detergent extract of the particulate fraction, we found copurification of phorbol diester receptors and protein kinase $C$ activity through several steps. The two activities copurified in a constant ratio. Inhibition of $\left[{ }^{3} \mathrm{H}\right]$ phorbol 12,13 dibutyrate $\left(\left[{ }^{3} \mathrm{H}\right] \mathrm{PDBu}\right)$ binding to the soluble receptor, as well as stimulation of the kinase activity, by a series of phorbol analogues demonstrated potency and specificity paralleling their known biological activities. Phorbol activation of protein kinase $\mathrm{C}$, in the absence of $\mathrm{Ca}^{2+}$, altered the phosphate acceptor substrate profile, at least in part, by an alteration of the apparent Michaelis constant $\left(K_{\mathrm{m}}\right)$ for histones. Thus the phorbol diesters may mediate their transmembrane effects by activation of protein kinase $\mathrm{C}$, with resultant alterations of cellular phosphoproteins.

\section{Methods}

Reagents. Solutions of calf thymus histone type III-S, calf thymus histone type V-S (H1), casein, salmon protamine-free base, ovalbumin from chicken egg (Sigma Chemical Co., St. Louis, MO), and myelin basic protein (a gift from Dr. Eugene Day, Duke University) were made up in deionized water to $1 \mathrm{mg} / \mathrm{ml}$ immediately before use. Diolein and phosphatidylserine (Sigma Chemical Co.) were stored dessicated at $0^{\circ} \mathrm{C}$ in chloroform. Just before use, the chloroform was evaporated and the lipids resuspended by sonication in deionized water to $500 \mu \mathrm{g} / \mathrm{ml}$. The stock solution of $\left[{ }^{3} \mathrm{H}\right] \mathrm{PDBu}$ (New England Nuclear, Boston, MA) was diluted to $1,000 \mathrm{nM}$ in $20 \mathrm{mM}$ Tris- $\mathrm{HCl}, \mathrm{pH} 7.5$, and $0.01 \%$ Pentax bovine serum albumin (Miles, Laboratories, Inc., Research Products Div., Elkhart, IN). PMA, PDBu, phorbol-12,13-didecanoate (PDD), and $4 \alpha$ phorbol-12,13-didecanoate (4 $\alpha$ PDD) (PL Biochemicals, Inc., Mil- waukee, WI) were dissolved in dimethyl sulfoxide at $10 \mathrm{mg} / \mathrm{ml}$ and stored at $0^{\circ} \mathrm{C}$. Just before use they were diluted with deionized water. [ $\gamma^{32}$ P]ATP (ICN Radiochemicals, Inc., Covina, CA) was diluted to 10 $\mu \mathrm{M}$ ATP with $2-4 \times 10^{5} \mathrm{cpm}\left[\gamma^{32} \mathrm{P}\right] \mathrm{ATP} / \mathrm{nmol}$.

Solubilization and partial purification of the phorbol receptor and protein kinase C. HL-60 cells (a gift from R. C. Gallo, National Institutes of Health) were grown in 3-liter spinner flasks in RPMI 1640 with 2 $\mathrm{mM}$ glutamine, $10 \mathrm{mM}$ Hepes, penicillin $(50 \mathrm{U} / \mathrm{ml})$, streptomycin $(50$ $\mu \mathrm{g} / \mathrm{ml}$ ), and $10 \%$ heat-inactivated fetal bovine serum (Gibco Laboratories, Grand Island, NY). At a density of $1.0-1.5 \times 10^{6} \mathrm{cells} / \mathrm{ml}$ the cells were harvested by centrifugation and washed two times with Dulbecco's phosphate-buffered saline without divalent ions. The cells were resuspended in $5 \mathrm{vol}$ of a lysis buffer consisting of $20 \mathrm{mM}$ Tris- $\mathrm{HCl}, \mathrm{pH} \mathrm{7.5,50}$ $\mathrm{mM}$ 2-mercaptoethanol, $2 \mathrm{mM}$ phenylmethylsulfonyl fluoride (PMSF), and $0.01 \%$ leupeptin (Sigma Chemical Co.) and $1 \mathrm{mM} \mathrm{CaCl}_{2}$ or $10 \mathrm{mM}$ EGTA and 2 mM EDTA. Cells were broken by sonication at maximal output (Biosonik, Bronwil Scientific, Rochester, NY) for $2 \mathrm{~min}$, then centrifuged at $100,000 \mathrm{~g}$ for $2 \mathrm{~h}$. With cells lysed in the presence of chelators, the resultant supernatant and pellet were termed the chelator cytosol and chelator pellet, respectively. With cells lysed in the presence of $\mathrm{CaCl}_{2}$, the resultant pellet was termed the $\mathrm{Ca}^{2+}$ pellet.

The chelator cytosol was brought up to $10 \%$ sucrose $(\mathrm{wt} / \mathrm{vol})$ and added to an excess of DEAE cellulose (Whatman Chemical Separation, Inc., Clifton, NJ) equilibrated in $20 \mathrm{mM}$ Tris- $\mathrm{HCl}, \mathrm{pH} 7.5,10 \mathrm{mM}$ EGTA, $2 \mathrm{mM}$ EDTA, $50 \mathrm{mM}$ 2-mercaptoethanol, and $10 \%$ sucrose. The mixture was added to a $4 \times 50-\mathrm{cm}$ column and washed with one column volume of the equilibration buffer then washed with 2 vol of $20 \mathrm{mM}$ Tris- $\mathrm{HCl}$, pH 7.5, 0.1 mM EGTA, $0.1 \mathrm{mM}$ EDTA, $50 \mathrm{mM} 2$ mercaptoethanol, and $10 \%$ sucrose. Proteins were eluted with a $200-\mathrm{ml}$ linear gradient of $0.0-0.3 \mathrm{M} \mathrm{NaCl}$ in the second wash buffer. Active fractions were pooled, concentrated by ultrafiltration, and applied to a $1 \times 45-\mathrm{cm}$ Sephadex G-150 (Pharmacia Fine Chemicals, Piscataway, $\mathrm{NJ}$ ) column equilibrated in the same buffer. Blue dextran (Pharmacia Fine Chemicals), bovine serum albumin (Sigma Chemical Co.), and lactalbumin (Sigma Chemical Co.) were run separately as markers.

The chelator pellet was resuspended by several strokes of a glassteflon tissue homogenizer in $20 \mathrm{mM}$ Tris- $\mathrm{HCl}, \mathrm{pH} 7.5,2 \mathrm{mM}$ PMSF, $10 \mathrm{mM}$ EGTA, $2 \mathrm{mM}$ EDTA, $50 \mathrm{mM}$ 2-mercaptoethanol, $0.01 \%$ leupeptin, and $20 \mathrm{mg} / \mathrm{ml}$ of 3-[(3-cholamido-propyl)dimethylammonia]1-propane sulfonate (CHAPS) and stirred at $4^{\circ} \mathrm{C}$ for $15 \mathrm{~min}$. The mixture was then centrifuged at $100,000 \mathrm{~g}$ for $2 \mathrm{~h}$. The resultant supernatant, termed detergent extract of pellet, was then carried through DEAE ion exchange as described above.

The $\mathrm{Ca}^{2+}$ pellet was resuspended by several strokes of a glass-teflon tissue homogenizer in $20 \mathrm{mM}$ Tris- $\mathrm{HCl}, \mathrm{pH} 7.5,5 \mathrm{mM}$ EGTA, $2 \mathrm{mM}$ EDTA, $2 \mathrm{mM}$ PMSF, and $0.01 \%$ leupeptin and stirred at $4^{\circ} \mathrm{C}$ for $1 \mathrm{~h}$. The mixture was centrifuged at $100,000 \mathrm{~g}$ for $2 \mathrm{~h}$. To the supernatant was added ammonium sulfate up to $21 \%$ (wt/vol), the precipitate was pelleted, and the resultant supernatant was brought up to $45 \%$ ammonium sulfate. The $21-45 \%$ ammonium sulfate pellet was collected by centrifugation and resuspended in $20 \mathrm{mM}$ Tris- $\mathrm{HCl}$, pH 7.5, 2 mM EGTA, $2 \mathrm{mM}$ EDTA, $50 \mathrm{mM}$ 2-mercaptoethanol, and $10 \%$ sucrose. After dialysis against this same buffer, the $21-45 \%$ ammonium sulfate pellet was applied to an excess of DEAE cellulose equilibrated with the same buffer. After a two column volume wash with this buffer, a $60-\mathrm{ml}$ linear gradient of $0.0-0.6 \mathrm{M} \mathrm{NaCl}$ in equilibration buffer was applied. Active fractions were pooled and used for further studies.

Phorbol receptor assay. Whole cell phorbol receptor assay was done according to the method described by Goodwin and Weinberg (34). The soluble phorbol receptor assay was done as previously described (30). Briefly, $50 \mu \mathrm{l}$ of receptor preparation was added to a $150 \mu \mathrm{l}$ mixture 
containing $20 \mathrm{nM}\left[{ }^{3} \mathrm{H}\right] \mathrm{PDBu}$ in $20 \mathrm{mM}$ Tris- $\mathrm{HCl}, \mathrm{pH} 7.5,1.0 \mathrm{mM}$ $\mathrm{CaCl}_{2}$, and $20 \mu \mathrm{g} / \mathrm{ml}$ phosphatidylserine. After incubation at $22^{\circ} \mathrm{C}$ for $15 \mathrm{~min}$, receptor bound and free $\left[{ }^{3} \mathrm{H}\right] \mathrm{PDBu}$ were separated by filtration through 1.8-ml AcA 44 columns (LKB). Radioactivity was measured in $15 \mathrm{ml}$ of Ultrafluor in a Beckman LS6800 counter (Beckman Instruments Inc., Fullerton, CA).

Protein kinase $C$ assay. Protein kinase $\mathrm{C}$ was assayed by measuring the incorporation of ${ }^{32} \mathrm{P}$ from $\left[\gamma^{32} \mathrm{P}\right] \mathrm{ATP}$ into specified phosphate acceptor substrates. The reaction mixture $(250 \mu \mathrm{l})$ consisted of $10 \mu \mathrm{M}$ ATP (2$\left.4 \times 10^{5} \mathrm{cpm}\left[\gamma^{32} \mathrm{P}\right] \mathrm{ATP} / \mathrm{nmol}\right), 20 \mu \mathrm{g} / \mathrm{ml}$ phosphatidylserine, $2 \mu \mathrm{g} / \mathrm{ml}$ diolein, either $1 \mathrm{mM}$ EGTA or $\mathrm{CaCl}_{2}$ as designated, $10 \mathrm{mM} \mathrm{MgCl}$, and $50 \mu \mathrm{l}$ of enzyme preparation. The reaction was started by the addition of enzyme source, incubated at $30^{\circ} \mathrm{C}$ for $10 \mathrm{~min}$, and stopped by the addition of $500 \mu \mathrm{g}$ of bovine albumin and $1 \mathrm{ml}$ of $4^{\circ} \mathrm{C} 25 \%$ trichloroacetic acid (TCA). Precipitated proteins were collected and washed with 10 $\mathrm{ml}$ of $4^{\circ} \mathrm{C} 25 \%$ TCA on Millipore HA filters $(0.45 \mu \mathrm{m}$, Millipore Continental Water Systems, Bedford, MA). Dried filters were suspended in $10 \mathrm{ml}$ Ultrafluor and ${ }^{32} \mathrm{P}$ counted in a Beckman LS6800 counter.

\section{Results}

Extraction and partial purification of the phorbol diester receptor and protein kinase $C$. Based on observations that $\sim 60 \%$ of rat brain phorbol diester receptors and protein kinase $\mathrm{C}$ were membrane-bound following tissue homogenization in the presence of $\mathrm{Ca}^{2+}(27,30)$, we initially homogenized HL-60 cells in $1 \mathrm{mM}$ $\mathrm{CaCl}_{2}$, separated the cytosol and crude particulate fractions by centrifugation, and then assayed for both phorbol diester receptors and protein kinase C activity. By Scatchard (35) analysis (data not shown), the starting HL-60 cells demonstrated a $K_{\mathrm{D}}$ $=21 \mathrm{nM}$ for $\left[{ }^{3} \mathrm{H}\right] \mathrm{PDBu}$ and 120,000 receptors/cell, in agreement with previous determinations $(17,18)$. As seen in Table $I, 93 \%$ of the total cellular receptors was recovered in the crude homogenate. The supernatant obtained after EGTA/EDTA extraction of the $100,000 \mathrm{~g}$ pellet was fractionated with ammonium sulfate; $12 \%$ of the total phorbol diester receptors was recovered in the $21-45 \%$ ammonium sulfate pellet. In four separate preparations, a yield of $10-13 \%$ was obtained at this step.

In an attempt to characterize all pools of the phorbol diester receptor and protein kinase $\mathrm{C}$, we also prepared cellular homogenates in the presence of chelators. The presence of chelators is necessary to characterize the cytosolic component in order to avoid $\mathrm{Ca}^{2+}$-mediated proteolysis (27). About $75 \%$ of the original whole cell phorbol diester receptors can be accounted for in the chelator cytosol and the chelator pellet combined. Hence, three pools of soluble phorbol diester receptors, cytosolic receptors prepared in the presence of chelators, membrane receptors extracted with detergent, and receptors extracted with chelators from $\mathrm{Ca}^{2+}$-prepared membranes, can be examined. These fractions represent at least $75 \%$ of total phorbol diester receptors (Table $\mathrm{I}$ ); the remainder of the receptor activity is either lost during the initial sonication and centrifugation (7$20 \%$ ) or remains associated with the particulate after chelator or detergent extraction (5-15\%).

We also attempted to follow the distribution of protein kinase $\mathrm{C}$ during the homogenization and extraction sequences. How-
Table I. Recovery of Phorbol Diester Receptors and Protein Kinase $C$

\begin{tabular}{|c|c|c|c|c|}
\hline Fraction & $\begin{array}{l}\text { Yield } \\
\text { phorbol } \\
\text { binding }\end{array}$ & $\begin{array}{l}\text { Specific activity } \\
{\left[{ }^{3} \mathrm{H}\right] \mathrm{PDBu}} \\
\text { binding }\end{array}$ & \multicolumn{2}{|c|}{$\frac{\text { Phorbol binding }}{\text { Protein kinase C }}$} \\
\hline & $\%$ & pmol/mg protein & & \\
\hline Whole cells & 100 & & & \\
\hline Cellular homogenate & 93 & & & \\
\hline Chelator cytosol & 55 & 4.5 & & \\
\hline Chelator pellet & 20 & 2.9 & & \\
\hline $\begin{array}{l}\text { Chelator extract } \mathrm{Ca}^{2+} \\
\text { pellet }\end{array}$ & 12 & & & \\
\hline $\begin{array}{l}\text { DEAE pool of chelator } \\
\text { cytosol }\end{array}$ & 40 & 55.1 & $\begin{array}{l}\mathrm{Ca}^{2+} \\
\text { PMA }\end{array}$ & $\begin{array}{l}0.0284 \\
0.0657\end{array}$ \\
\hline $\begin{array}{l}\text { DEAE pool of detergent } \\
\text { extract }\end{array}$ & 11 & 11.1 & $\begin{array}{l}\mathrm{Ca}^{2+} \\
\text { PMA }\end{array}$ & $\begin{array}{l}0.0292 \\
0.0928\end{array}$ \\
\hline $\begin{array}{l}\text { DEAE pool of chelator } \\
\text { extract }\end{array}$ & 4 & & $\begin{array}{l}\mathrm{Ca}^{2+} \\
\text { PMA }\end{array}$ & $\begin{array}{l}0.0305 \\
0.0924\end{array}$ \\
\hline $\begin{array}{l}\text { G-150 pool of DEAE- } \\
\text { purified chelator }\end{array}$ & & & $\mathrm{Ca}^{2+}$ & 0.0300 \\
\hline cytosol & 12 & 95.4 & PMA & 0.0908 \\
\hline
\end{tabular}

After measurement of whole cell phorbol diester receptors, the cells were resuspended in buffers containing $20 \mathrm{mM}$ Tris- $\mathrm{HCl}, \mathrm{pH} 7.5,50$ $\mathrm{mM}$ 2-mercaptoethanol, $2 \mathrm{mM}$ PMSF, $0.01 \%$ leupeptin and either 1 $\mathrm{mM} \mathrm{CaCl} 2$ or $10 \mathrm{mM}$ EGTA and $2 \mathrm{mM}$ EDTA and lysed by sonication (cellular homogenate). The homogenates were centrifuged at $100,000 \mathrm{~g}$ for $2 \mathrm{~h}$ and the fractions termed chelator cytosol, chelator pellet, and $\mathrm{Ca}^{2+}$ pellet obtained. The $\mathrm{Ca}^{2+}$ cytosol was discarded. The chelator cytosol was applied to DEAE cellulose and eluted with a linear $(0-0.3 \mathrm{M}) \mathrm{NaCl}$ gradient. Active fractions were pooled, their total $\left[{ }^{3} \mathrm{H}\right] \mathrm{PDBu}$ binding activity determined and compared with whole cell total binding activity (percent yield). $\left[{ }^{3} \mathrm{H}\right] \mathrm{PDBu}$ binding of the pooled fractions (counts per minute per milliliter) was compared with protein kinase activity of the same pooled fractions stimulated by either $500 \mu \mathrm{M} \mathrm{CaCl}_{2}$ and $20 \mu \mathrm{g} / \mathrm{ml}$ phosphatidylserine or $16 \mathrm{nM} \mathrm{PMA}$ and $20 \mu \mathrm{g} / \mathrm{ml}$ phosphatidylserine (counts per minute per milliliter) and expressed as a ratio of phorbol binding/protein kinase activity. Part of the pooled fractions from the DEAE column of the chelator cytosol was subjected to Sephadex G-150 gel sizing chromatography. Active fractions were pooled and percent recovery and phorbol binding/ protein kinase ratio determined as above. The chelator pellet was suspended by tissue homogenization in the original lysis buffer, an aliquot taken for $\left.{ }^{3} \mathrm{H}\right] \mathrm{PDBu}$ binding and CHAPS added to a final concentration of $20 \mathrm{mg} / \mathrm{ml}$ and stirred for $15 \mathrm{~min}$ at $4^{\circ} \mathrm{C}$. The detergent extraction solution was centrifuged and the supernatant applied to a DEAE cellulose column and eluted with a linear $(0-0.3 \mathrm{M}) \mathrm{NaCl}$ gradient. Active fractions were pooled, percent recovery $\left[{ }^{3} \mathrm{H}\right] \mathrm{PDBu}$ binding and phorbol binding/protein kinase ratios determined as above. The $\mathrm{Ca}^{2+}$ pellet was resuspended by glass-teflon homogenization in $20 \mathrm{mM}$ Tris- $\mathrm{HCl}$, pH 7.5, 5 mM EGTA, 2 mM EDTA, 2 mM PMSF, and $0.01 \%$ leupeptin and incubated for $1 \mathrm{~h}$ at $4^{\circ} \mathrm{C}$. A 21$45 \%$-ammonium sulfate fraction was prepared and subjected to DEAE cellulose chromatography. Active fractions were pooled and percent recovery [ $\left.{ }^{3} \mathrm{H}\right] \mathrm{PDBu}$ binding and phorbol binding/protein kinase ratios determined as above. Protein was determined according to the method of Bradford (61) and picomoles $\left[{ }^{3} \mathrm{H}\right] \mathrm{PDBu}$ per milligram protein determined and reported as specific activity. 
ever, $\mathrm{Ca}^{2+}$ - and lipid-stimulated kinase activity was evident only after ammonium sulfate or DEAE ion exchange steps. An endogenous inhibitor or specific phosphatase masks the activity during the early steps. Therefore, parallel calculations of protein kinase $\mathrm{C}$ and phorbol diester receptor yields were not possible.

Three points are worthy of mention. Treatment of the cells with $5 \mathrm{mM}$ diisopropylfluorophosphate before sonication did not increase the yield of kinase or receptor (31). Second, when cells were washed with $\mathrm{Ca}^{2+}$-containing buffers before homogenization, subsequent extraction of the crude particulate fraction with chelators was less efficient $(n=4)$. Therefore, cells were always washed without divalent ions before cell disruption in the lysis buffer. Finally, the chelator extraction mixture of 5 $\mathrm{mM}$ EGTA and $2 \mathrm{mM}$ EDTA was found to be superior to 20 mM EGTA alone and to chelators plus $500 \mathrm{mM} \mathrm{NaCl}$.

Next, the cytosolic, the chelator-extracted, and the detergentextracted fractions were purified by DEAE ion exchange chromatography. Fractions were assayed for specific phorbol diester receptor activity and for $\mathrm{Ca}^{2+} /$ phospholipid-dependent and independent protein kinase activity. In addition, the active cytosolic and detergent extracted column fractions were assayed for PMA-stimulated protein kinase activity, while the active chelator extracted column fractions were pooled and used for further phorbol activated kinase studies (see below). As illustrated in Fig. $1 A-C$, the phorbol diester receptor activity and the $\mathrm{Ca}^{2+} /$ phospholipid-stimulated and PMA-stimulated kinase activities all coeluted as a single peak $(n=3 ; n=6 ; n=3$, respectively). Greater than $50 \%$ of the original phorbol diester receptors could be accounted for in the combined active DEAE fractions (Table I).

At this stage of purification the kinase exhibited an absolute dependence on added phospholipid and $\mathrm{Ca}^{2+}$ or PMA. The phorbol diester receptor shared the lipid requirement and was also stimulated by exogenous $\mathrm{Ca}^{2+}$. The active fractions from the cytosolic DEAE column were applied to a Sephadex G-150 sizing chromatography column as shown in Fig. 2. Again, the phorbol diester receptor and the $\mathrm{Ca}^{2+} /$ phospholipid- and PMAstimulated kinase activities comigrated as a single peak, just ahead of bovine serum albumin. Similar results were seen when the chelator-extracted pool was subjected to sizing chromatography (data not shown).

Since it was not possible to compare yields of phorbol receptor and protein kinase $C$, the ratio of the two activities during the later stages of purification was determined. The active fractions from the three ion exchange columns and from the sizing column were each pooled, dialyzed against a common buffer, and assayed for specific phorbol diester receptor activity and phorbol and $\mathrm{Ca}^{2+} /$ phospholipid-dependent kinase activity. As shown in Table $I$, the ratios of phorbol binding to protein kinase activities was very similar, independent of the method of solubilization or purification.

Characterization of the partially purified soluble phorbol diester receptor. Fig. 3 depicts the saturation curve for binding of $\left[{ }^{3} \mathrm{H}\right] \mathrm{PDBu}$ to aliquots of the pooled DEAE fractions of chelator extracted membranes. Saturation was evident above $25 \mathrm{nM}$ with $50 \%$ of the sites occupied at $7.5 \mathrm{nM}\left[{ }^{3} \mathrm{H}\right] \mathrm{PDBu}$. Scatchard analysis (35) showed a strictly linear relationship with a derived $K_{\mathrm{D}}=8.1 \mathrm{nM}$.

As stated above, $\mathrm{Ca}^{2+}$ and phospholipid were required in order to demonstrate high-affinity binding of $\left[{ }^{3} \mathrm{H}\right] \mathrm{PDBu}$ to the soluble receptor. To further characterize this requirement, $\mathrm{Ca}^{2+}$ and phosphatidylserine dose-response curves were done as shown in Fig. 4. In the presence of $20 \mu \mathrm{g} / \mathrm{ml}$ phosphatidylserine, $\left[{ }^{3} \mathrm{H}\right] \mathrm{PDBu}$ binding was maximal at $10^{-4} \mathrm{M} \mathrm{CaCl}_{2}$ (Fig. $4 \mathrm{~A}$ ). In the presence of EGTA, about one-third maximal binding was seen, while $\mathrm{CaCl}_{2}$ concentrations above $10^{-3} \mathrm{M}$ inhibited binding to the unstimulated level. The absolute phospholipid requirement is depicted in Fig. $4 \mathrm{~B}$. The curve has the shape of a typical saturation curve, with half-maximal stimulation at $20 \mu \mathrm{g} / \mathrm{ml}$ and saturation $>100 \mu \mathrm{g} / \mathrm{ml}$.

Phorbol activation of partially purified protein kinase $C$. Because of the observations that the phorbol diesters could directly activate rat brain protein kinase $C(19,30)$, similar experiments were undertaken using the enzyme partially purified from HL-60 cells. Using the pooled fractions from chelator extracted DEAE chromatography, the effects of phosphatidylserine, diolein, and/or PMA on kinase activity, as a function of $\mathrm{Ca}^{2+}$ concentration, were determined (Fig. 5). In the presence of EGTA, neither diolein nor phosphatidylserine, alone or together, activated protein kinase $\mathrm{C}$. However, in the presence of $10^{-6} \mathrm{M} \mathrm{Ca}^{2+}$, the addition of phosphatidylserine dramatically increased the kinase activity. Increasing the $\mathrm{Ca}^{2+}$ concentration brought about a dose-dependent increase in enzyme activity with maximum activity at $10^{-4} \mathrm{M} \mathrm{Ca}^{2+}$. The further addition of the unsaturated diacylglycerol, diolein, was associated with only a modest $(n=3)$ enhancement of kinase activity at less than maximum $\mathrm{Ca}^{2+}$ concentrations. Likewise, PMA alone, at $16 \mathrm{nM}$, did not alter the enzyme. However, the addition of PMA plus phosphatidylserine, even in the presence of EGTA, greatly enhanced the protein kinase activity to $60 \%$ of the maximum $\mathrm{Ca}^{2+} /$ phospholipid-stimulated activity. The further addition of only $10^{-6} \mathrm{M} \mathrm{Ca}^{2+}$ was associated with maximum enzyme activity. The stimulation of kinase activity by the combination of PMA at $16 \mathrm{nM}$ plus optimal concentrations of $\mathrm{Ca}^{2+}$, phosphatidylserine and diolein was identical to the stimulated activity seen with either inducer alone (i.e., the two methods of activation were not additive).

Knowing the optimal conditions for enzyme activation, phosphate acceptor substrate specificity was examined. Because of initial differences seen in the phosphate acceptor substrate specificity of $\mathrm{Ca}^{2+} /$ phospholipid-stimulated and PMA-stimulated kinase activities, studies were done to clarify this difference. As seen in Fig. $6 \mathrm{~A}$, Histone $\mathrm{H} 1$, histone type IIIS, and myelin basic protein were all excellent phosphate acceptors for the $\mathrm{Ca}^{2+}$ stimulated kinase (solid lines). The histones were also good substrates for PMA-stimulated enzyme (dashed lines) and the initial differences seen at the usual substrate concentrations of $200 \mu \mathrm{g} / \mathrm{ml}$, could be explained by a change in $K_{\mathrm{m}}$ (Fig. $6 \mathrm{~B}$ ). However, the differences seen using myelin basic protein may be more complex and may involve more than just an alteration in $K_{\mathrm{m}}$. We could not achieve concentrations of myelin basic protein in the assay, which were high enough to determine an 

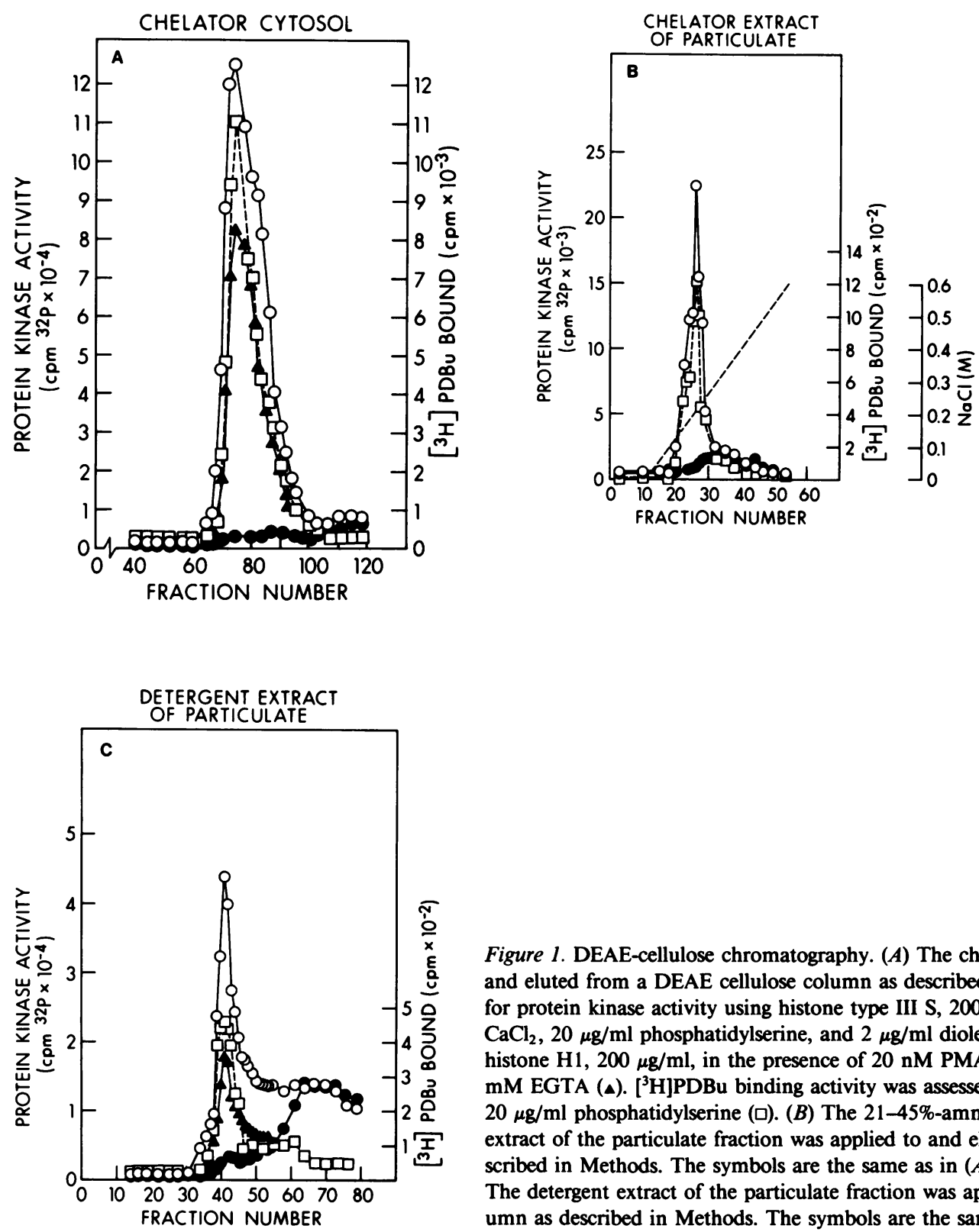

Figure 1. DEAE-cellulose chromatography. $(A)$ The chelator cytosol was prepared, applied to and eluted from a DEAE cellulose column as described in Methods. Fractions were assayed for protein kinase activity using histone type III S, $200 \mu \mathrm{g} / \mathrm{ml}$, in the presence of $500 \mu \mathrm{M}$ $\mathrm{CaCl}_{2}, 20 \mu \mathrm{g} / \mathrm{ml}$ phosphatidylserine, and $2 \mu \mathrm{g} / \mathrm{ml}$ diolein (o) or $1 \mathrm{mM}$ EGTA (•), or using histone $\mathrm{H1}, 200 \mu \mathrm{g} / \mathrm{ml}$, in the presence of $20 \mathrm{nM}$ PMA, $20 \mu \mathrm{g} / \mathrm{ml}$ phosphatidylserine, and 1 mM EGTA ( $\Lambda$ ). [ ${ }^{3} \mathrm{H}$ ]PDBu binding activity was assessed in the presence of $1 \mathrm{mM} \mathrm{CaCl}$ and $20 \mu \mathrm{g} / \mathrm{ml}$ phosphatidylserine (ㅁ). (B) The $21-45 \%$-ammonium sulfate fraction of the chelator extract of the particulate fraction was applied to and eluted from a DEAE column as described in Methods. The symbols are the same as in $(A)$ except for $\mathrm{NaCl}$ gradient (-.-.-). (C) The detergent extract of the particulate fraction was applied to and eluted from a DEAE column as described in Methods. The symbols are the same as in $(A)$.

accurate $K_{\mathrm{m}}$ with the PMA-stimulated kinase. In similar studies, protamine, casein, and ovalbumin were modest-to-poor acceptor substrates in all instances (data not shown).

Phorbol diester stereospecificity of the soluble phorbol diester receptor and of protein kinase $C$ activation. The specificity of the soluble phorbol diester receptor was examined. As illustrated in Fig. 7, the inhibition of $\left[{ }^{3} \mathrm{H}\right] \mathrm{PDBu}$ binding by various phorbol analogues was assessed over a range of concentrations. Binding inhibition mirrored known biologic potency. PMA, the most potent phorbol diester analogue, completely inhibited binding of $\left[{ }^{3} \mathrm{H}\right] \mathrm{PDBu}$ at $20 \mathrm{nM}$ with $50 \%$ inhibition at $3 \mathrm{nM}$. PDD and PDBu are less potent as inducers of HL-60 maturation. Near maximal binding inhibition for both was seen at $250 \mathrm{nM}$ with $50 \%$ inhibition at $21 \mathrm{nM}$ and $7 \mathrm{nM}$, respectively. The biologically inactive phorbol diester, $4 \alpha \mathrm{PDD}$, did not inhibit $\left[{ }^{3} \mathrm{H}\right] \mathrm{PDBu}$ binding over the concentration range of 50 to $500 \mathrm{nM}$.

Finally, the dose-response and stereospecificity of the activation of protein kinase $C$ by phorbol diester analogues was examined. The results are illustrated in Fig. 8. Since it was known that phorbol stimulation altered the $K_{\mathrm{m}}$ for the histone 


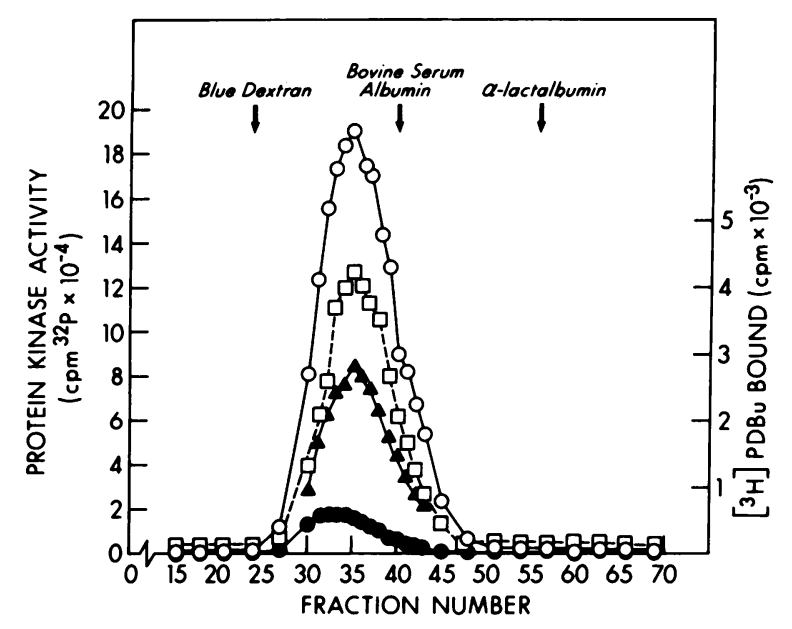

Figure 2. Sephadex G-150 chromatography. Active fractions from the chelator cytosol DEAE column were subjected to Sephadex G-150 chromatography as described in Methods. Fractions were assayed for protein kinase activity using histone type III-S, $200 \mu \mathrm{g} / \mathrm{ml}$, in the presence of $500 \mu \mathrm{M} \mathrm{CaCl}_{2}, 20 \mu \mathrm{g} / \mathrm{ml}$ phosphatidylserine, and $2 \mu \mathrm{g} /$ $\mathrm{ml}$ diolein (0) or $1 \mathrm{mM}$ EGTA (•) or using histone $\mathrm{H1}, 200 \mu \mathrm{g} / \mathrm{ml}$, in the presence of $20 \mathrm{nM}$ PMA, $20 \mu \mathrm{g} / \mathrm{ml}$ phosphatidylserine, and 1 mM EGTA ( () . $\left[{ }^{3} \mathrm{H}\right] \mathrm{PDBu}$-binding activity was assessed in the presence of $1 \mathrm{mM} \mathrm{CaCl}{ }_{2}$ and $20 \mu \mathrm{g} / \mathrm{ml}$ phosphatidylserine $(\square)$. The vertical arrows denote the elution positions of the standard markers.

phosphate acceptor substrates, two acceptors were used, histone type III-S and histone $\mathrm{H}-1$. Using type III-S as substrate (Fig. $8 \mathrm{~A}$ ), PMA, in the presence of EGTA and phosphatidylserine, was the most potent activator of protein kinase C. Maximum enzyme activity occurred at $50 \mathrm{nM}$ and $50 \%$ activation at $8 \mathrm{nM}$ PMA. However, PDBu was only slightly less potent with equal stimulation at $100 \mathrm{nM}$ and $50 \%$ activation at $16 \mathrm{nM}$. PDD was a less potent enzyme activator with maximum kinase activity at $250 \mathrm{nM}$ and $50 \%$ activity at $30 \mathrm{nM}$. Activation by all three analogues resulted in the same maximal kinase activity. The biologically inactive analogue $4 \alpha \mathrm{PDD}$ was ineffective as an activator of protein kinase $C$ even at $500 \mathrm{nM}$. Changing the phosphate acceptor substrate to histone $\mathrm{H} 1$ did not alter the rank

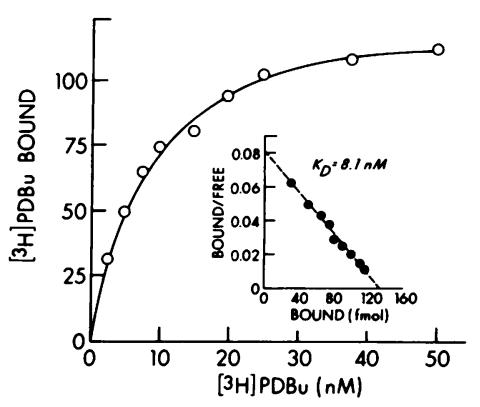

Figure 3. Binding of $\left[{ }^{3} \mathrm{H}\right] \mathrm{PDBu}$ as a function of increasing concentration. Data points are averages of duplicate measurements of $50 \mu \mathrm{l}$ from pooled DEAE fractions. Scatchard analysis is shown in the insert. This is representative of three such experiments with derived $K_{\mathrm{D}}=7.0,8.1$, $10.0 \mathrm{nM}\left[{ }^{3} \mathrm{H}\right] \mathrm{PDBu}$.
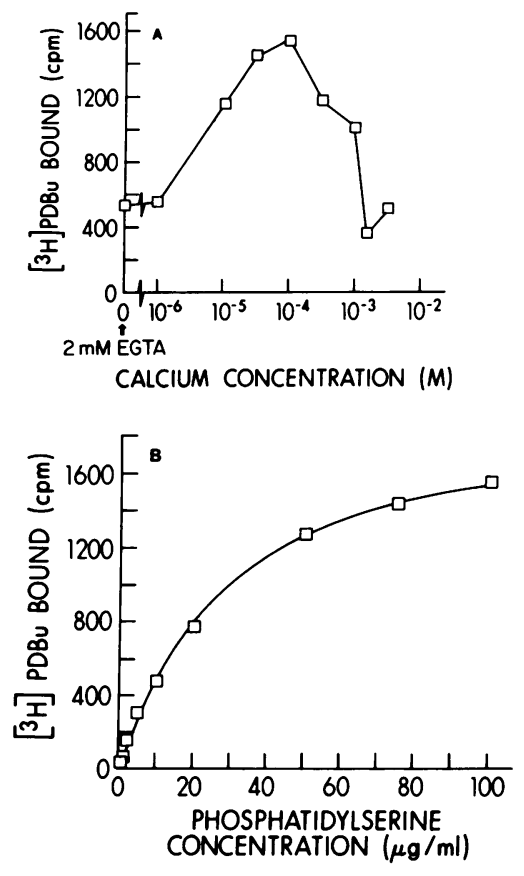

Figure 4. (A) Binding of $\left[{ }^{3} \mathrm{H}\right] \mathrm{PDBu}$ as a function of $\mathrm{CaCl}_{2}$ concentration. $50-\mu l$ aliquots of pooled DEAE fractions were assayed for $\left[{ }^{3} \mathrm{H}\right] \mathrm{PDBu}$ binding activity in the presence of $20 \mu \mathrm{g} / \mathrm{ml}$ phosphatidylserine and $20 \mathrm{nM}\left[{ }^{3} \mathrm{H}\right] \mathrm{PDBu}$ and various concentrations of $\mathrm{CaCl}_{2}$ or $2 \mathrm{mM}$ EGTA. Data points are averages of duplicate measurements. Simultaneous nonsaturable binding, assessed in the presence of a 100-fold excess $(5 \mu \mathrm{M})$ of nonradioactive PDBu were consistently $<100 \mathrm{cpm}$ ${ }^{3} \mathrm{H}$. (B) Binding of $\left[{ }^{3} \mathrm{H}\right] \mathrm{PDBu}$ as a function of phosphatidylserine concentration. 50- $\mu$ l aliquots of pooled DEAE

fractions were assayed for $\left[{ }^{3} \mathrm{H}\right] \mathrm{PDBu}$ binding in the presence of 1 $\mathrm{mM} \mathrm{CaCl}{ }_{2}$ and $20 \mathrm{nM}\left[{ }^{3} \mathrm{H}\right] \mathrm{PDBu}$ and various concentrations of phosphatidylserine. Points are averages of duplicates and nonsaturable binding was as in $(A)$. These experiments are representative of two such experiments.

order potency of the phorbol diester analogues (Fig. $8 \mathrm{~B}$ ). Under these conditions, maximal kinase activation occurred at 100 $\mathrm{nM}$ PMA with an $\mathrm{ED}_{50}=11 \mathrm{nM}$ PMA. PDBu- and PDDstimulated kinase activity showed $\mathrm{ED}_{50}$ values of $24 \mathrm{nM} P D B u$ and $70 \mathrm{nM}$ PDD. Again, the same maximal kinase activity was achieved with each of the phorbol analogues. $4 \alpha$ PDD was ineffective as an enzyme activator. Hence, as regards phorbol

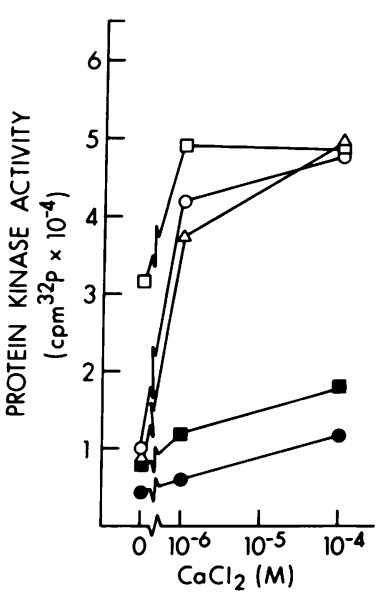

Figure 5. Activation of protein kinase $\mathrm{C}$ by PMA and lipids as a function of $\mathrm{CaCl}_{2}$ concentration. Chelator-free pooled DEAE fractions from chelator extract were assayed for protein kinase activity using histone type III-S, $200 \mu \mathrm{g} /$ $\mathrm{ml}$, in the presence of $1 \mathrm{mM}$ EGTA or added $\mathrm{CaCl}_{2}$ at $1-100$ $\mu \mathrm{M}$. Incubation mixtures contained: $2 \mu \mathrm{g} / \mathrm{ml}$ diolein (๑); $16 \mathrm{nM}$ PMA (a); $20 \mu \mathrm{g} / \mathrm{ml}$ phosphatidylserine $(\Delta) ; 2 \mu \mathrm{g} / \mathrm{ml}$ diolein and 20 $\mu \mathrm{g} / \mathrm{ml}$ phosphatidylserine (0); 16 nM PMA and $20 \mu \mathrm{g} / \mathrm{ml}$ phosphatidylserine (ㅁ). Data points are averages of duplicate measurements and this data is representative of three experiments. 

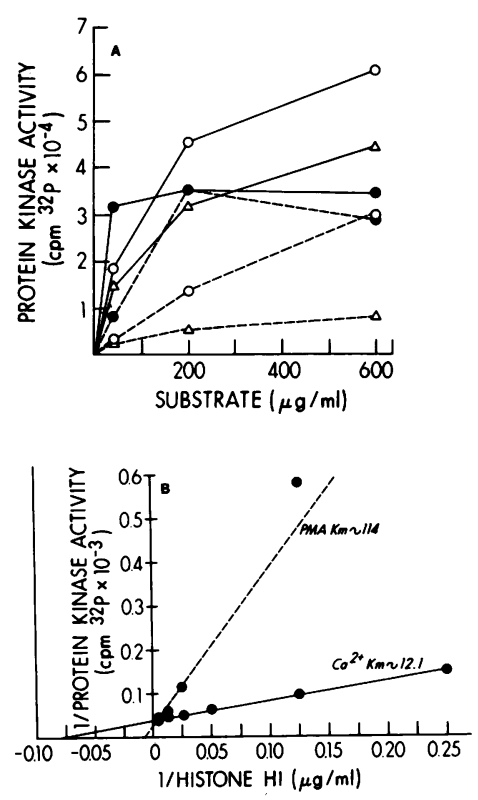

Figure 6. Activity of protein kinase $\mathrm{C}$ stimulated by PMA or $\mathrm{CaCl}_{2}$. (A) Activity as a function of phosphate acceptor substrate concentration. Pooled chelator cytosol DEAE fractions were assayed for kinase activity stimulated by either 500 $\mu \mathrm{M} \mathrm{CaCl}_{2}, 20 \mu \mathrm{g} / \mathrm{ml}$, phosphatidylserine, and $2 \mu \mathrm{g} / \mathrm{ml}$ diolein (solid lines) or 16 nM PMA, $20 \mu \mathrm{g} / \mathrm{ml}$ phosphatidylserine and $1 \mathrm{mM}$ EGTA (dashed lines) in addition to $0-600 \mu \mathrm{g} / \mathrm{ml}$ of the following substrates: histone type III $\mathrm{S}(\mathrm{O})$, histone H1 (๑), or myelin basic protein $(\Delta)$. (B) LineWeaver-Burk plot of the reciprocal of the protein kinase activity stimulated by either $500 \mu \mathrm{M} \mathrm{CaCl}_{2}, 20$

$\mu \mathrm{g} / \mathrm{ml}$ phosphatidylserine, and $2 \mu \mathrm{g} / \mathrm{ml}$ diolein (solid line) or $16 \mathrm{nM}$ PMA, $20 \mu \mathrm{g} / \mathrm{ml}$ phosphatidylserine, and $1 \mathrm{mM}$ EGTA (dashed line) as a function of the reciprocal of various concentrations of histone H1 substrate. Data points were obtained by averaging duplicate counts from two separate experiments.

diester activation of protein kinase $\mathrm{C}$, enzyme activation potency reflects the known biologic potency of the phorbol analogues.

\section{Discussion}

The HL-60 cell line was established from a patient with acute promyelocytic leukemia and has proven to be an experimentally

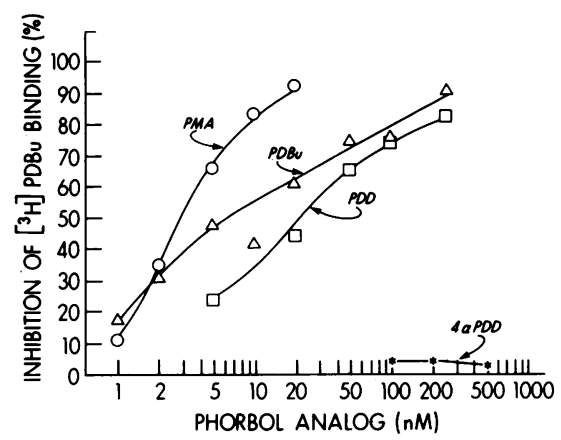

Figure 7. Inhibition of $\left[{ }^{3} \mathrm{H}\right] \mathrm{PDBu}$ binding by various phorbol diester analogues. 50- $\mu \mathrm{l}$ aliquots from pooled DEAE fractions were incubated with $20 \mathrm{nM}\left[{ }^{3} \mathrm{H}\right] \mathrm{PDBu}, 1 \mathrm{mM} \mathrm{CaCl}{ }_{2}$, and $20 \mu \mathrm{g} / \mathrm{ml}$ phosphatidylserine in addition to one of the following phorbol analogues: PMA at 1-20 nM (0); PDD at 5-250 nM (ם); PDBu at 5-250 nM ( $\Delta$ ); $4 \alpha \mathrm{PDD}$ at $100-500 \mathrm{nM}\left({ }^{*}\right)$. Data points are averages of duplicate values from two separate experiments.

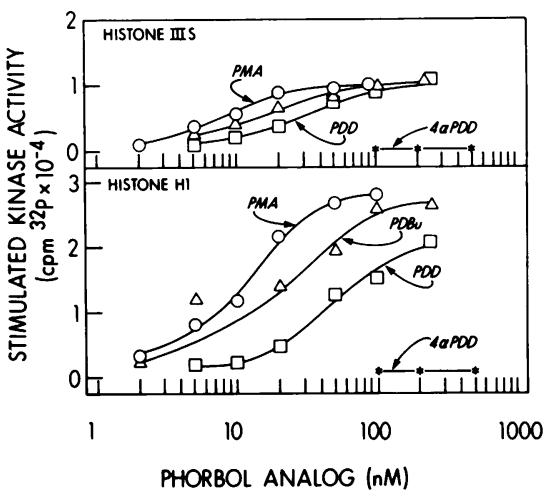

Figure 8. (A) Activation of protein kinase $\mathrm{C}$ by phorbol analogues utilizing histone III-S as substrate. 50- $\mu$ l samples from pooled DEAE fractions were assayed for protein kinase activity in the presence of $1 \mathrm{mM}$ EGTA, $20 \mu \mathrm{g} / \mathrm{ml}$ phosphatidylserine, and $200 \mu \mathrm{g} / \mathrm{ml}$ of histone III-S in addi-

tion to one of the following: PMA at 2-100 nM (0); PDD at 5-250 $\mathrm{nM}(\square)$; PDBu at 5-250 nM ( $\Delta) ; 4 \alpha \mathrm{PDD}$ at $100-500 \mathrm{nM}\left({ }^{*}\right)$. Data points are averages of duplicate values. $(B)$ Activation of protein kinase $\mathrm{C}$ by phorbol analogues utilizing $\mathrm{H} 1$ as substrate. $50-\mu \mathrm{l}$ of the same source as in $(A)$ were assayed for kinase activity in the presence of $1 \mathrm{mM}$ EGTA, $20 \mu \mathrm{g} / \mathrm{ml}$ phosphatidylserine, and $200 \mu \mathrm{g} / \mathrm{ml}$ of histone $\mathrm{H} 1$ in addition to one of the following: PMA at 2-100 nM (o); PDD at 5-250 nM (ם); PDBu at 2-250 nM ( $\Delta$ ); $4 \alpha$ PDD at 100-500 $\mathrm{nM}\left({ }^{*}\right)$. Data points are averages of duplicate values from a single experiment and are representative of data from three experiments.

accessible model for the study of myeloid differentiation (37, 38). The phorbol diester tumor promoter, PMA, has been the most potent and efficacious inducer of macrophage maturation of this cell line (3-5). The macrophage nature of the differentiated cells has been repeatedly confirmed $(4,6-8)$. The abilities of a series of phorbol diester analogues to induce macrophage maturation followed a rank order of potency and specificity consistent with their known abilities to promote tumors (5).

Other cell lines have also been found to be responsive to the differentiating effects of the phorbol diesters. The myeloblastic leukemia cell lines KG-1 and ML-3 and the monocytic leukemia cell line THP-1 were also induced to macrophage maturity with PMA treatment $(7,39)$. This success with differentiation of continuous cell lines was extended to fresh explants of human leukemia cells. Cells from patients with acute and chronic myelocytic or myelomonocytic leukemias have been treated in primary culture with the phorbol diesters. The treated cells universally acquired differentiated macrophage characteristics (40-42).

Phorbol diester-induced leukemic cell differentiation exhibited the potency and stereospecificity characteristic of a receptormediated response. Driedger and Blumberg (43) and Delclos et al. (44) developed [ $\left.{ }^{3} \mathrm{H}\right] \mathrm{PDBu}$ as a specific ligand for the phorbol diester receptor and this ligand was used to demonstrate specific receptors in a variety of normal and transformed cells and tissues, including the HL-60 cell line $(16,45,46)$. Solanki et al. (17) found 80,000 phorbol diester receptors per cell with a $K_{\mathrm{D}}=50$ $\mathrm{nM}$ in both phorbol responsive and unresponsive HL-60 cells. Cooper et al. (18) found 190,000 receptors per HL-60 cell with 
a $K_{\mathrm{D}}=23 \mathrm{nM}$. The phorbol diesters also appear to exert their effects in fresh leukemic explants via specific receptors (46a).

However, the biochemical nature of the phorbol diester receptors had remained unknown until recently. Castagna et al. (19) demonstrated direct activation of rat brain $\mathrm{Ca}^{2+} /$ phospholipid-dependent protein kinase $\mathrm{C}$ by the active phorbol analogues. We confirmed this observation and also showed that soluble phorbol diester receptors copurified with protein kinase $\mathrm{C}$ from rat brain (30) lending further support to the identity of protein kinase $\mathrm{C}$ as the phorbol diester receptor. The very recent reports $(32,33)$ demonstrating that both activities from mouse brain apparently reside in a single molecule, further strengthen this argument.

In this paper we have extended these observations to the HL-60 cell line in which the phorbol diesters elicit a known biological response. The initial whole cell phorbol receptor measurements of 120,000 receptors/cell with a $K_{\mathrm{D}}=21 \mathrm{nM}$ were similar to those previously reported $(17,18)$. Following cell lysis and fractionation by centrifugation, the sum of the cytosolic and membrane-associated receptors nearly equaled the total quantity of receptors measured in the intact cells. This suggests that both the cytosolic and membrane-associated receptors are measured in the whole cell binding assay. But if approximately one-third of the total receptors are cytosolic in the presence of $\mathrm{Ca}^{2+}$, and two-thirds are cytosolic in the presence of divalent ion chelators $(27,30)$, how can they be measured in the whole cell receptor assay? Recently Kraft et al. (47) and Kraft and Anderson (48), using a thymoma cell line and yolk sac cells, demonstrated vastly decreased cytosolic protein kinase $C$ activity and increased membrane-associated activity after whole cell treatment with PMA. Indeed, using this thymoma cell line, EL4, Sando and Young (49) have very recently identified a cytosolic, high-affinity phorbol diester receptor. Thus, phorbol diester exposure appears to bring about translocation of cytosolic protein kinase $\mathrm{C} /$ phorbol diester receptor to the membrane, so that most of the kinase/receptor is membrane-bound and hence accessible to the radioligand.

We attempted to study all forms of the phorbol diester receptor that could be solubilized. The phorbol diester receptor and protein kinase $C$ activities copurified through ammonium sulfate precipitation, DEAE ion exchange, and Sephadex G-150 sizing chromatography from all pools studied. In fact, in all studies done to date, specific phorbol diester receptors have always been associated with the protein kinase activity. Through these steps, the phorbol diester receptor developed a requirement for both exogeneous $\mathrm{Ca}^{2+}$ and phospholipid. Identical requirements have been well documented for protein kinase $C(26$, 27). In addition, similar requirements have recently been demonstrated for a soluble phorbol diester receptor found in several tissue types $(31,32,49,50)$. In this study, optimal receptor binding and maximum kinase activity occurred at the identical $\mathrm{Ca}^{2+}$ concentration of $10^{-4} \mathrm{M}$. In addition, the relative mobilities of both activities from HL-60 cells on sizing chromatography are in accord with that found previously for protein kinase $\mathrm{C}$ from other sources $(26,27)$.
The probable identity of protein kinase $C$ and the phorbol receptor was further supported by the studies of kinase activation by the phorbol analogues. PMA, at biologically relevant concentrations, directly activated protein kinase $C$, even in the absence of $\mathrm{Ca}^{2+}$. This activation was dose dependent and stereospecific, with activation potency correlated with known biologic potency for tumor promotion and induction of cell differentiation. In addition, phorbol activation of protein kinase $\mathrm{C}$ brought about a change in the phosphate acceptor substrate profile of the enzyme by altering the $K_{\mathrm{m}}$ for the histone substrates, although the differences noted using myelin basic protein as substrate may be more complex. It would seem that the phorbol diesters exert their effects on the HL-60 cell by initially binding to stereospecific, high-affinity sites on protein kinase C. Resultant activation of this enzyme may be reflected in vivo by increased membrane-associated kinase activity with subsequent changes in cellular phosphoproteins. Indeed, we have characterized several phosphoprotein changes in HL-60 cells after treatment with PMA and other active phorbol analogues (Vandenbark, G. R., and J. E. Niedel, manuscript in preparation).

The linkage of the phorbol diester receptor with protein kinase $\mathrm{C}$ has interesting implications. Recently much evidence has accumulated demonstrating a causal role for protein phosphorylation in oncogenesis induced by retroviruses (51-54). Modulation of normal growth by epidermal growth factor and platelet-derived growth factor may also involve activation of membrane-associated protein kinases (55-57). Tumor promotion and cellular differentiation now also appear to be tightly associated with activation of a protein kinase. Thus, we are now attempting to characterize the endogenous phosphate acceptor substrates for phorbol diester-activated protein kinase C in HL60 cells.

In summary, in the HL-60 cell line we have: (a) demonstrated soluble phorbol diester-binding protein from three cellular pools accounting for at least $75 \%$ of the total whole cell phorbol diester receptors, and shown them to have the affinity, saturability, and stereospecificity expected of the phorbol diester receptor; $(b)$ shown that the phorbol diester receptor and $\mathrm{Ca}^{2+} /$ phospholipiddependent protein kinase $\mathrm{C}$ cosolubilize and copurify in a constant ratio; $(c)$ demonstrated direct activation of protein kinase $\mathrm{C}$ by the phorbol diesters at biologically active concentrations and with a specificity paralleling the known biologic potency of the various analogues. With these data and the rapid cellular phosphoprotein changes seen in PMA-treated HL-60 cells (Vandenbark, G. R., and J. E. Niedel, manuscript in preparation), we propose that phorbol binding to and activation of protein kinase $\mathrm{C}$ may be causal in the induction of macrophage maturation of myeloid leukemic cells by the phorbol diesters. Biologically relevant (i.e., lymphokines, monokines) inducers of cellular differentiation may activate protein kinase as well (58-60).

Note added in proof. Feuerstein and Cooper (1983. J. Biol. Chem. 258:10786-10793) have demonstrated rapid changes in HL-60 phosphoproteins induced by PMA. 


\section{Acknowledgments}

We thank Ms. Gloria Sloan for expert technical assistance and Ms. Karen Scheideler for typing the manuscript.

This work was supported by grants from the National Institute of Allergy and Infectious Diseases (AI 18308), the Chicago Community Trust/Searle Scholars Program (81-G-113), the March of Dimes Birth Defects Foundation Basil O'Connor starter research grant program (5334) and by U. S. Public Health Service grant NCI 5T32 CA09307-05.

\section{References}

1. Berenblum, I. 1954. A speculative review: the probable nature of promoting action and its significance in the understanding of the mechanism of carcinogenesis. Cancer Res. 14:471-477.

2. Blumberg, P. M. 1980. In vitro studies on the mode of action of the phorbol esters, potent tumor promoters: Part I. CRC Crit. Rev. Tox. 8:153-197.

3. Rovera, G., T. G. O'Brien, and L. Diamond. 1979. Induction of differentiation in human promyelocytic leukemia cells by tumor promoters. Science (Wash. DC). 204:868-870.

4. Rovera, G., D. Santoli, and C. Damsky. 1979. Human promyelocytic leukemia cells differentiate into macrophage-like cells when treated with a phorbol diester. Proc. Natl. Acad. Sci. USA. 76:2779-2783.

5. Huberman, E., and M. Callahan. 1979. Induction of terminal differentiation in human promyelocytic leukemia cells by tumor-promoting agents. Proc. Natl. Acad. Sci. USA 76:1293-1297.

6. Mulder, A., S. Alexander, C. D. Englefriest, E. G. Kr. von dem Borne, and J. L. Strominger. 1981. Characterization by immunoprecipitation, of myeloid and monocyte-specific antigens present on the human promyelocytic cell line (HL-60) in three stages of differentiation. Proc. Natl. Acad. Sci. USA. 78:5091-5095.

7. Koeffler, H. P., M. Bar-Eli, and M. Territo. 1981. Phorbol ester effect on differentiation of human myeloid leukemia cell lines blocked at different stages of maturation. Cancer Res. 41:919-926.

8. Newberger, P. E., R. D. Baker, S. L. Hansen, R. A. Duncan, and J. S. Greenberger. 1981. Functionally deficient differentiation of HL60 promyelocytic leukemia cells induced by phorbol myristate acetate. Cancer Res. 41:1861-1865.

9. Weinberg, J. B. 1981. Tumor cell killing by phorbol ester-differentiated human leukemia cells. Science (Wash. DC). 213:655-657.

10. Huberman, E. C. Weeks, A. Herrman, M. Callahan, and T. Slaga. 1981. Alterations in polyamine levels induced by phorbol diesters and other agents that promote differentiation in human promyelocytic leukemia cells. Proc. Natl. Acad. Sci. USA. 78:1062-1066.

11. Luk, D. G., C. I. Civin, R. M. Weissman, and S. B. Baylin. 1982. Ornithine decarboxylase: essential in proliferation but not differentiation of human promyelocytic leukemia cells. Science (Wash. DC). 216:75-77.

12. Cassileth, P. A., D. Suholet, and R. A. Cooper. 1981. Changes in phosphatidylcholine metabolism in human acute promyelocytic leukemia cells stimulated to differentiate by phorbol ester. Blood. 58:237243.

13. Cabot, M. C., and C. T. Welsh. 1981. Fatty acid metabolism in phorbol ester-differentiating human leukemia cells. Cancer Res. 41:4910 4915.

14. Cossu, G., A. L. Kuo, S. Pessano, L. Warren, and R. A. Cooper. 1982. Decreased synthesis of high-molecular-weight glycopeptides in human promyelocytic leukemic cells (HL-60) during phorbol ester-induced macrophage differentiation. Cancer Res. 42:484-489.

15. Kornberg, A., A. Treves, E. A. Rachmilewitz, and E. Fibach. 1982. Generation of procoagulant activity (PCA) by phorbol esterinduced macrophages derived from a leukemic promyelocytic cell line, HL-60. Blood. 59:1061-1066.

16. Shoyab, M., and G. Todaro. 1980. Specific high-affinity cell membrane receptors for biologically active phorbol and ingenol esters. Nature (Lond.). 288:451-455.

17. Solanki, V., T. J. Slaga, M. Callahan, and E. Huberman. 1981. Down-regulation of specific binding of $\left[20-{ }^{3} \mathrm{H}\right]$ phorbol 12, 13-dibutyrate and phorbol ester-induced differentiation of human promyelocytic leukemia cells. Proc. Natl. Acad. Sci. USA. 78:1722-1725.

18. Cooper, R. A., A. D. Braunwald, and A L. Kuo. 1982. Phorbol ester induction of leukemic cell differentiation is a membrane-mediated process. Proc. Natl. Acad. Sci. USA. 79:2865-2869.

19. Castagna, M., Y. Takai, K. Kaibuchi, K. Sano, U. Kiddawa, and Y. Nishizuka. 1982. Direct activation of calcium-activated, phospholipid-dependent protein kinase by tumor-promoting phorbol esters. J. Biol. Chem. 257:7847-7851.

20. Inoue, M., A. Kishimoto, Y. Takai, and Y. Nishizuka. 1977. Studies on a cyclic nucleotide-independent protein kinase and its proenzyme in mammalian tissues. J. Biol. Chem. 252:7610-7616.

21. Minakuchi, R., Y. Takai, B. Yu, and Y. Nishizuka. 1981. Widespread occurrence of calcium-activated, phospholipid-dependent protein kinase in mammalian tissues. J. Biochem. 89:1651-1654.

22. Kuo, J. F., R. G. G. Andersson, B. C. Wise, L. Mackerlova, I. Salomousson, N. L. Brackett, N. Katoh, M. Shoji, and R. Wrenn. 1980. Calcium-dependent protein kinase: widespread occurrence in various tissues and phyla of the animal kingdom and comparison of the effects of phospholipid, calmodulin, and trifluoperizine. Proc. Natl. Acad. Sci. USA. 77:7039-7043.

23. Helfman, D. M., K. C. Barnes, J. M. Kinkade, W. R. Vogler, M. Shoji, and J. F. Kuo. 1983. Phospholipiú-sensitive $\mathrm{Ca}^{2+}$-dependent protein phosphorylation system in various types of leukemic cells from human patients and in human leukemic cell lines HL-60 and K562, and its inhibition by alkyl-lysophospholipid. Cancer Res. 43:2955-2961.

24. Kawahara, Y., Y. Takai, R. Minakuchi, K. Sano, and $\bar{Y}$. Nishizuka. 1980. Possible involvement of $\mathrm{Ca}^{2+}$-activated, phospholipid-dependent protein kinase in platelet activation. J. Biochem. 88:913-916.

25. Ogaw, Y., Y. Takai, Y. Kawahara, S. Kimura, and Y. Nishizuka. 1981. New possible regulatory system for protein phosphorylation in human peripheral lymphocytes: characterization of a calcium-activated, phospholipid-dependent protein kinase. J. Immunol. 127:1369-1374.

26. Wise, B. C., R. L. Raynor, and J. E. Kuo. 1982. Phospholipidsensitive $\mathrm{Ca}^{2+}$-dependent protein kinase from heart: I-purification and general properties. J. Biol. Chem. 257:8481-8488.

27. Kikkawa, U., Y. Takai, R. Minakuchi, S. Inohara, and Y. Nishizuka. 1982. Calcium-activated, phospholipid-dependent protein kinase from rat brain: subcellular distribution, purification, and properties. $J$. Biol. Chem. 257:13341-13348.

28. Shatzman, R. C., R. L. Raynor, R. B. Fritz, and J. F. Kuo. 1983. Purification to homogeneity, characterization, and monoclonal antibodies of phospholipid-sensitive $\mathrm{Ca}^{2+}$-dependent protein kinase from spleen. Biochem. J. 209:435-443.

29. Kishimoto, A., N. Kajikawa, M. Shiota, and Y. Nishizuka. 1983. Proteolytic activation of calcium-activated, phospholipid-dependent protein kinase by calcium-dependent neutral protease. J. Biol. Chem. 258:1156-1164 
30. Niedel, J. E., L. Kuhn, and G. R. Vandenbark. 1983. Phorbol diester receptor copurifies with protein kinase C. Proc. Natl. Acad. Sci. USA. 80:36-40.

31. Leach, K. L., M. L. James, and P. M. Blumberg. 1983. Characterization of a specific phorbol ester aporeceptor in mouse brain cytosol. Proc. Natl. Acad. Sci. USA. 80:4208-4212.

32. Ashendel, C. L., J. M. Staller, and R. K. Boutwell. 1983. Solubilization, purification, and reconstitution of a phorbol ester receptor from the particulate protein fraction of mouse brain. Cancer Res. 43:4327-4332.

33. Ashendel, C. L., J. M. Staller, and R. K. Boutwell. 1983. Protein kinase activity associated with a phorbol ester receptor purified from mouse brain. Cancer Res. 43:4333-4337.

34. Goodwin, B. J., and J. B. Weinberg. 1982. Receptor-mediated modulation of human monocyte, neutrophil, lymphocyte, and platelet function by phorbol diesters. J. Clin. Invest. 70:699-706.

35. Scatchard, G. 1948. The attractions of proteins for small molecules and ions. Ann. NY Acad. Sci. 51:660-672.

36. Amrein, P. C., and T. P. Stossel. 1980. Prevention of degradation of human polymorphonuclear leukocyte proteins by diisopropylfluorophosphate. Blood. 56:442-447.

37. Collins, S. T., R. C. Gallo, and R. E. Gallagher. 1977. Continuous growth and differentiation of human myeloid leukaemic cells in suspension culture. Nature (Lond.). 270:347-349.

38. Gallagher, R., S. Collins, J. Trujillo, K. McCredie, M. Ahearn, S. Tsai, R. Metzgar, G. Aulakh, R. Ting, F. Ruscetti, and R. Gallo. 1979. Characterization of the continuous, differentiating myeloid cell line (HL-60) from a patient with acute promyelocytic leukemia. Blood. 54:713-733.

39. Tsuchiya, S., Y. Kobayashi, Y. Goto, H. D. Kumura, S. Nakae, T. Konno, and K. Tada. 1982. Induction of maturation in cultured human monocytic leukemia cells by a phorbol diester. Cancer Res. 42:1530-1536.

40. Koeffler, H. P., M. Bar-Eli, and M. Territo. 1980. Phorbol diesterinduced macrophage differentiation of leukemic blasts from patients with human myelogenous leukemia. J. Clin. Invest. 66:1101-1108.

41. Pegoraro, L., J. Abraham, R. A. Cooper, A. Lewis, B. Lange, P. Meo, and G. Rovera. 1980. Differentiation of human leukemia in response to 12-O-tetra-decanoyl phorbol-13-acetate in vitro. Blood. 55:859-862

42. Fibach, E., and E. A. Rachmilewitz. 1981. Tumour promoters induce macrophage differentiation in human myeloid cells from patients with acute and chronic myelogenous leukemia. Br. J. Haematol. 47:203210.

43. Driedger, P. E., and P. M. Blumberg. 1980. Specific binding of phorbol ester tumor promoters. Proc. Natl. Acad. Sci. USA. 77:567571.

44. Delclos, K. B., D. S. Nagle, and P. M. Blumberg. 1980. Specific binding of phorbol ester tumor promoters to mouse skin. Cell. 19:10251032.

45. Dumphy, W. G., K. B. Delclos, and P. M. Blumberg. 1980. Characterization of specific binding of $\left[{ }^{3} \mathrm{H}\right]$ phorbol 12,13 -dibutyrate and $\left[{ }^{3} \mathrm{H}\right]$ phorbol 12-myristate 13-acetate to mouse brain. Cancer Res. 40:3635-3641.

46. Horowitz, A. D., E. Greenbaum, and I. B. Weinstein. 1981. Identification of receptors for phorbol ester tumor promoters in intact mammalian cells and of an inhibitor of receptor binding in biologic fluids. Proc. Natl. Acad. Sci. USA. 78:2315-2319.

46a.Goodwin, B. J., J. O. Moore, and J. B. Weinberg. 1984. Specific receptors for phorbol diesters on human myeloid and lymphoid leukemia cells: comparable binding despite different cellular responses. Blood. In press.

47. Kraft, A. S., W. B. Anderson, H. L. Cooper, and J. J. Sando. 1982. Decrease in cytosolic calcium/phospholipid-dependent protein kinase activity following phorbol ester treatment of EL4 thymoma cells. J. Biol. Chem. 257:13193-13196.

48. Kraft, A. S., and W. B. Anderson. 1983. Phorbol esters increase the amount of $\mathrm{Ca}^{2+}$, phospholipid-dependent protein kinase associated with plasma membrane. Nature (Lond.). 301:621-623.

49. Sando, J. J., and M. C. Young. 1983. Identification of highaffinity phorbol ester receptor in cytosol of EL 4 thymoma cells: requirement for calcium, magnesium, and phospholipids. Proc. Natl. Acad. Sci. USA. 80:2642-2646.

50. Ashendel, C. L., J. M. Staller, and R. K. Boutwell. 1983. Identification of a calcium- and phospholipid-dependent phorbol ester binding activity in the soluble fraction of mouse tissue. Biochem. Biophys. Res. Commun. 111:340-345.

51. Hunter, T., and B. M. Sefton. 1980. The transforming gene product of Rous sarcoma virus phosphorylates tyrosine. Proc. Natl. Acad. Sci. USA. 77:1311-1315.

52. Collett, M. S., A. F. Purchia, and R. L. Erikson. 1980. Avian sarcoma virus transforming protein, pp $60^{\mathrm{sc}}$, shows protein kinase activity specific for tyrosine. Nature (Lond.). 285:167-169.

53. Sefton, B. M., T. Hunter, K. Beemon, and W. Eckhart. 1980. Evidence that the phosphorylation of tyrosine is essential for cellular transformation by Rous sarcoma virus. Cell. 20:807-816.

54. Witte, O. N., A. Dasgupta, and D. Baltimore. 1980. The Abelson murine leukemia virus protein is phosphorylated in vitro to form phosphotyrosine. Nature (Lond.). 283:826-831.

55. Ushiro, H., and S. Cohen. 1980. Identification of phosphotyrosine as a product of epidermal growth factor-activated protein kinase in A431 cell membranes. J. Biol. Chem. 255:8363-8365.

56. Nishimura, J., J. S. Huang, and T. F. Deuel. 1982. Plateletderived growth factor stimulates tyrosine-specific protein kinase activity in Swiss mouse 3T3 cell membranes. Proc. Natl. Acad. Sci. USA. 79:43034307.

57. Ek, B., and C. H. Heldin. 1982. Characterization of a tyrosinespecific kinase activity in human fibroblast membranes stimulated by platelet-derived growth factor. J. Biol. Chem. 257:10486-10492.

58. Abrahm, J. L., and R. Smiley. 1981. Modification of normal human myelopoiesis by 12-O-tetradecanoyl-phorbol-13-acetate (TPA). Blood. 58:1119-1126.

59. Olsson, I., T. Olofsson, and N. Mauritzon. 1981. Characterization of mononuclear blood cell-derived differentiation inducing factors for the human promyelocytic leukemia cell line HL-60. J. Natl. Cancer Inst. 67:1225-1230.

60. Chiao, J. W., W. F. Freitag, J. C. Steinmetz, and M. Andreeff. 1981. Changes of cellular markers during differentiation of HL-60 promyelocytes. Leuk. Res. 5:477-489.

61. Bradford, M. 1976. A rapid and sensitive method for the quantitation of microgram quantities of protein utilizing the principle of protein-dye binding. Anal. Biochem. 72:248-254. 